\title{
RELIEF EVALUATION FOR THE PURPOSES OF RECREATION AND TOURISM - CASE STUDY RAVNA MOUNTAIN AND PALE VALLEY
}

DOI: http://dx.doi.org/10.18509/GBP.2017.10

UDC: 911.52:796.5(497.6)

\begin{abstract}
Jelena Golijanin
University of East Sarajevo, Faculty of Philosophy Pale, Department of Geography, Bosnia and Herzegovina
\end{abstract}

\begin{abstract}
Possibility for development of tourism in certain area is affected by relief characteristics as stimulating or limiting factors. Landforms contributions to geodiversity of area by increasing its scientific, educational and recreational-touristic potential. Evaluation of relief for purposes of recreation and tourism in the example of Ravna Mountain and Pale Valley was carried by usage of AHP multi-criteria analysis and rating method.

The evaluation process of the relief is determined by five criteria: elevation, slope, vertical dissection, aspect and morphographic characteristics. In the process of reclassification were used criterion maps made in the GIS. Results of the evaluation showed that the relief in the studied area has a significant impact on the ability for development and application recreational tourism. Relief features of Ravna Mountain have real possibilities for improvement of existing and development of new, mass tourism activities, particularly during the summer months. Qualitatively most valuable fields, favourable for recreation, covers almost one third of the studied area.
\end{abstract}

Keywords: relief evaluation, applied geomorphology, AHP method, Bosnia and Herzegovina.

\section{INTRODUCTION}

On the possibility of tourism development in certain area, relief characteristics acts as stimulating or limiting factors. Landforms contribute to geodiversity of area by increasing its scientific, educational and recreational tourism potential. Evaluation of the relief is one of the most difficult tasks in the context of evaluating physical potential [1].

On morphometric and morphographic characteristics of relief depends possibility of using area for purpose of different forms of tourism and recreation. Evaluation of morphometric and morphographic characteristics of relief is based on appropriate geostatistical and cartographic methods and has great significance in the process of evaluating the potential of environment. The relief of area as a component of natural environment which is changing slowest and least, the basic element of qualitative area characteristics and as such is suitable for long-term planning of life and work. Out of it depends other elements: air, hydrography, soil and vegetation cover, distribution of settlements, communications, agriculture, industry and tourism. In the studied mountain-valley area was developed winter tourism, which in recent years records tendency of growth, and that is why this work aims to determine the potential of relief, and relief dependent most appropriate terrain for development of tourism and recreation especially in summer period of year. 


\section{GEOGRAPHICAL POSITION OF STUDIED AREA}

The studied area is located southeast of Sarajevo (Figure 1), and it covers approx. 117 $\mathrm{km}^{2}$. It has a dominant mountainous character (the highest point of area is $1640 \mathrm{~m}$, amplitude of altitude is $920 \mathrm{~m}$, and the average height is $1064 \mathrm{~m}$ ). Larger part of Ravna Mountain, is karstified elevated plane, which gradually descend to Pale Valley. It is part of large Jahorina massif. Pale Valley has polygenetic origin, descent by faults in comparison to the surrounding area of positive morphostructures [2]. This area is characterized by early development of winter tourism, as a result of favorable relief characteristics and the proximity of urban area of Sarajevo, what has contributed to organization of XIV Winter Olympic Games in Sarajevo in 1984.

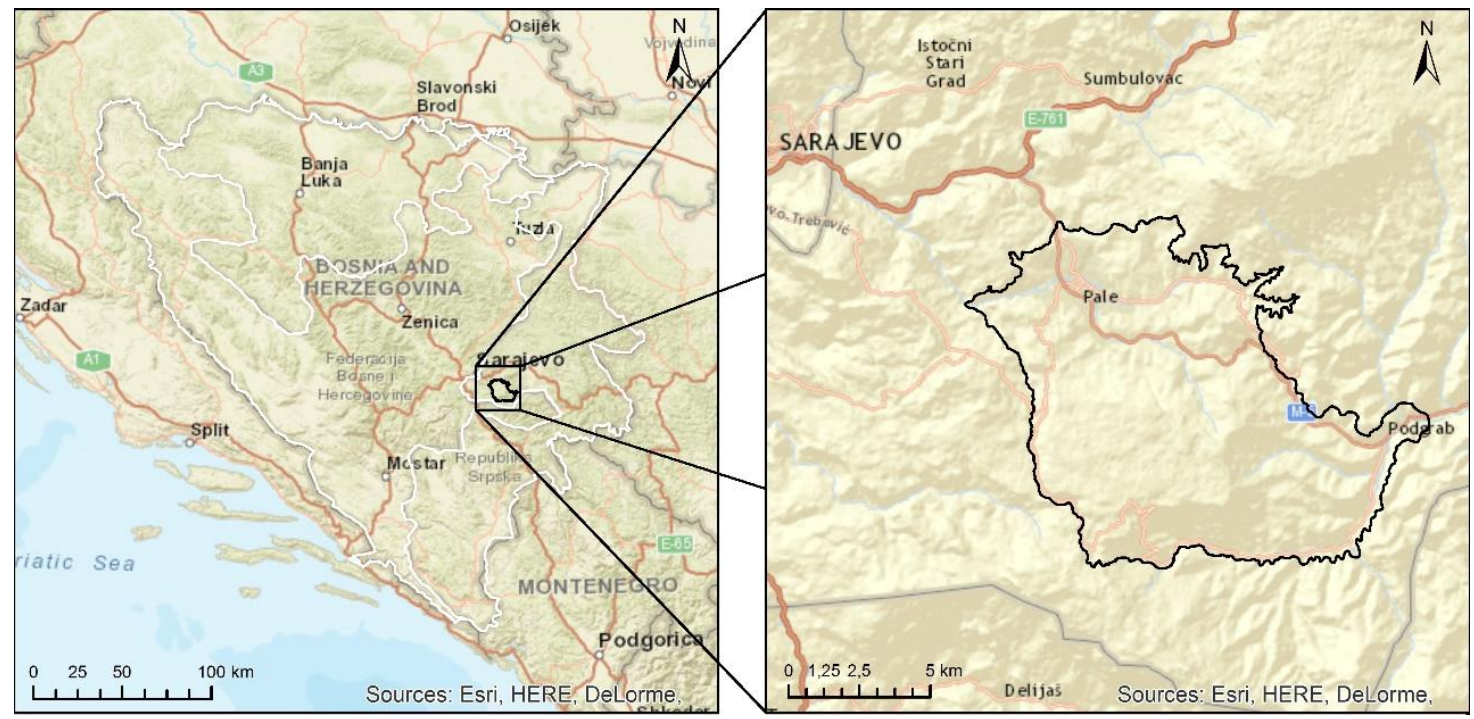

Figure 1. Location of Ravna Mountain and Pale Valley in Bosnia and Herzegovina

\section{METHODOLOGY}

Relief evaluation for the purposes of recreation and tourism in the example of Ravna Mountain and Pale Valley was carried based on a combination of AHP multi-criteria analysis and methods of rating. In process of relief evaluation, was determined five criteria: elevation, slope, vertical dissection, aspect and morphographic characteristics [2], [3]. This was preceded by phases of data collection and data preparation: digitalization, statistical analysis, defining the concept of a database for each criterion, classification of data sets, rating and creation of criterion maps based on results of rating method [4], [5], [6], [1], (Table 1).

After determining of criteria, we have performed their quality evaluation. It has been formed a scale with nine rating categories, wherein highest relative value has category 9 and the lowest category 1 (adopted scale of 9 rating categories is not in relation with Saaty's scale). Introduced in the eliminatory category. In the process of reclassification were used criterion maps made in the GIS, which is respected spatial dimension.

After it we have established a matrix of comparison, Saaty's evaluation scale (Table 2) [7], based on which was obtained dominance ratio of criteria - there have been calculate the weights of criteria (w) (Table 4). 
Table 1. Rating scale

\begin{tabular}{clll}
\hline $\begin{array}{l}\text { Rating } \\
\text { category }\end{array}$ & $\begin{array}{l}\text { Score } \\
\text { range }\end{array}$ & Qualitative description & $\begin{array}{l}\text { Valuable level of spatial unit } \\
\text { (regions) }\end{array}$ \\
\hline 9 & $8-9$ & Most suitable & Most valuable regions \\
\hline 8 & $7-8$ & Very suitable & Very valuable regions \\
\hline 7 & $6-7$ & Mostly suitable & Mostly valuable regions \\
\hline 6 & $5-6$ & Relative satisfying & Relative satisfying regions \\
\hline 5 & $4-5$ & Mostly less suitable & Mostly less valuable regions \\
\hline 4 & $3-4$ & Relative unsuitable & Relative unsuitable regions \\
\hline 3 & $2-3$ & Mostly unsuitable & Mostly unsuitable regions \\
\hline 2 & $1-2$ & Unsuitable & Unsuitable regions \\
\hline 1 & $0-1$ & Very unsuitable & Very unsuitable regions \\
\hline elim. & elim. & Eliminatory & Eliminatory regions \\
\hline
\end{tabular}

Table 2. Saaty's evaluation scale

\begin{tabular}{|c|c|c|}
\hline $\begin{array}{l}\text { Intensity of } \\
\text { importance }\end{array}$ & Definition & Explanation \\
\hline 1 & Equal importance & Two activities contribute equally to the objective \\
\hline 2 & Weak or slight & \\
\hline 3 & $\begin{array}{l}\text { Moderate } \\
\text { importance of one } \\
\text { over another }\end{array}$ & Experience and judgment strongly favor one activity over another \\
\hline 4 & Moderate plus & \\
\hline 5 & Strong importance & Experience and judgment strongly favor one activity over another \\
\hline 6 & Strong plus & \\
\hline 7 & Very strong & $\begin{array}{l}\text { An activity is strongly favored and its dominance demonstrated in } \\
\text { practice }\end{array}$ \\
\hline 8 & $\begin{array}{l}\text { Very strong to } \\
\text { extreme }\end{array}$ & \\
\hline 9 & Extreme importance & $\begin{array}{l}\text { The evidence favoring one activity over another is of the highest } \\
\text { possible order of affirmation }\end{array}$ \\
\hline $2,4,6,8$ & Intermediate values & When compromise is needed \\
\hline $1 / 2,1 / 3, \ldots 1 / 9$ & Reciprocal & \\
\hline
\end{tabular}

Along with this process is calculated degree of matrix consistency (CR), which is 0.06 (if $\mathrm{CR} \leq 0.10$ the result is considered sufficiently accurate and assessment of the relative weights are acceptably). By summarizing raster maps we have obtained suitability map. This process is done by using GIS tools to summarize the grid, per a formula that includes the $\mathrm{w}_{\mathrm{i}}$ weights of criteria.

$$
s_{x, y}=\sum_{i=1}^{n} w_{i} \cdot v_{i ; x, y}
$$

Where is: $\mathrm{s}_{\mathrm{x}, \mathrm{y}}$ - value of $\mathrm{x}, \mathrm{y}$ of suitability map; $\mathrm{w}_{\mathrm{i}}$ - weight coefficient of $i$ criterion; $\mathrm{v}_{\mathrm{i} ; \mathrm{x}, \mathrm{y}}$ - value of $\mathrm{x}, \mathrm{y}$ cell of $i$ criterion.

\section{RESULTS AND DISCUSSION}

Level of relief suitability for development of various forms of recreational tourism, among others, includes the physical and aesthetic suitability and availability. Physical suitability is reflected in influence of certain morphometric relief characteristics on higher or lower limits which reduce the potential value of relief. This particularly refers to destructive gravitational landslide processes, collapsing and crumbling which are 
expressed on steep ground (important from point of safety, and potential danger to tourists). Aesthetic suitability, attractiveness and looks of certain forms of relief, is also an important determinant of relief value for defined forms of recreation. Determination of aesthetic suitability, or attractiveness have more subjective nature. Some landforms may be particularly aesthetically attractive to tourists, but they can also affect to mobility (canyons, limestone pavements, etc.). Availability, as an indicator of touristic suitability of area, includes outside and inside availability. Outside availability represents the distance of a certain tourist areas from urban areas and major roads, while the inside includes links within the touristic area.

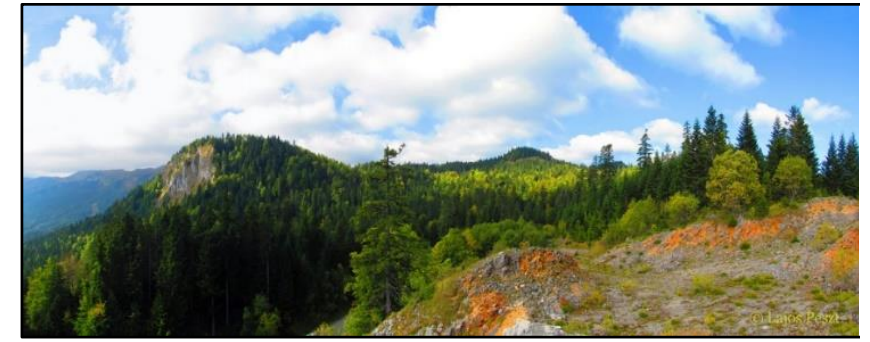

Figure 2: Ravna Mountain peak Zelena Glavica $(1640 \mathrm{~m})$

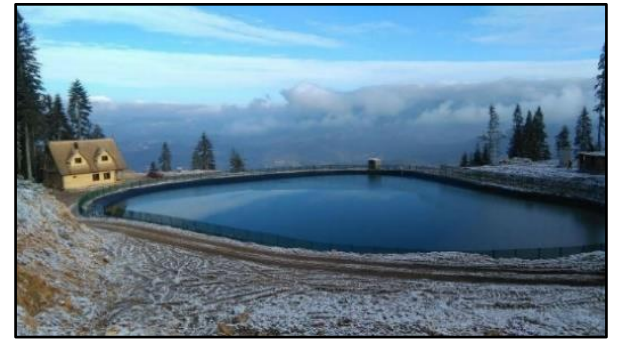

Figure 3: Ravna Mountain lake on karst surface

Hypsometric features of relief are reflected through influence of altitude on human health and improvement of general psychophysical condition of visitors. The mountains of moderate latitudes have therapeutic qualities. Highlighted are an altitude that are beneficial to certain types of illnesses, for example altitude up to $1200 \mathrm{~m}$ are favorable for pulmonary diseases, etc., and altitude up to $2000 \mathrm{~m}$ are particularly suited to person exhausted from stress of modern life. Higher parts of the Ravna mountain fits with in rank of therapeutic components that mountains provide. Slope and vertical dissection of relief affecting the accessibility and are important for planning of hiking and biking trails, as well as the aesthetic advantage of relief. On the other hand, parts of terrain with dominant dissected and steeples relief, showed to be extremely useful for certain extreme forms of recreation. In planning of purpose and usage of area for recreation an important role plays aspect of the relief, where the terrain with dominated sunny side give greater advantages when it comes to locating and arranging tourist and recreational complex. Aspect in some extent affect the characteristics of the microclimate of certain parts of the area, which is reflected in recreational and therapeutic components. Some morphographic relief features are characterized by exceptional attractiveness and wealth of forms. They assist in evaluation in precise allocation of touristic attractive relief forms in a certain area.

Mountain areas located close to urban areas, due to the lower population density and their relief and other natural characteristics, are often qualified in the category of regions suitable for recreation and certain types of recreational tourism. In evaluation process is determined five relief criteria. Received scores, ie. the level of suitability of attributes are obtained on basis of examples used in works which treat such and similar issues (Table 3), [8], [9], [10], [11], [12], [6], [1], etc. Attributes and ratings are adjusted to possibilities and conditions offered by studied area. 
Table 3. Quality evaluation of relief for recreation and tourism

\begin{tabular}{|c|c|c|c|c|c|c|c|c|c|}
\hline $\begin{array}{l}\text { Altitude } \\
\text { (m) }\end{array}$ & $\dot{\vec{g}}$ & $\begin{array}{l}\text { Slope } \\
\left({ }^{\circ}\right)\end{array}$ & $\dot{\overrightarrow{\breve{g}}}$ & $\begin{array}{l}\text { Vert. dissec. } \\
\left(\mathbf{m} / \mathbf{k m}^{2}\right)\end{array}$ & $\dot{\bar{\Xi}}$ & Aspect $\left(^{\circ}\right)$ & $\dot{\vec{\Xi}}$ & $\begin{array}{l}\text { Morphographic } \\
\text { characteristics }\end{array}$ & $\dot{\vec{\Xi}}$ \\
\hline$<800$ & 3 & $0-2$ & 9 & $0-5$ & 9 & flat & 9 & Canyons, d.i stream & 9 \\
\hline $800-900$ & 4 & $2-5$ & 8 & $5-30$ & 8 & $\mathrm{~S}$ & 9 & Upland drainages & 5 \\
\hline $900-1000$ & 5 & $5-12$ & 7 & $30-100$ & 7 & SE, SW & 7 & U-shaped valleys & 7 \\
\hline $\begin{array}{c}1000- \\
1250\end{array}$ & 7 & $12-32$ & 5 & $100-300$ & 5 & $\mathrm{E}, \mathrm{W}$ & 5 & Plains & 9 \\
\hline $\begin{array}{c}1250- \\
1500\end{array}$ & 9 & $32-55$ & 3 & $300-800$ & 3 & NE, NW & 3 & Open slopes & 5 \\
\hline \multirow[t]{3}{*}{$>1500$} & 7 & $>55$ & 1 & $>800$ & 1 & $\mathrm{~N}$ & 1 & Upper slopes, mesas & 6 \\
\hline & & & & & & & & Local ridges, hills & 7 \\
\hline & & & & & & & & Mt tops, high ridges & 9 \\
\hline
\end{tabular}

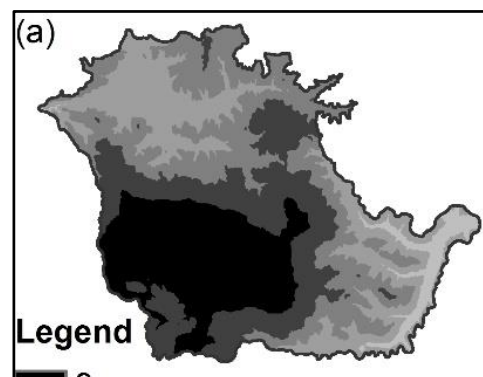

(d)

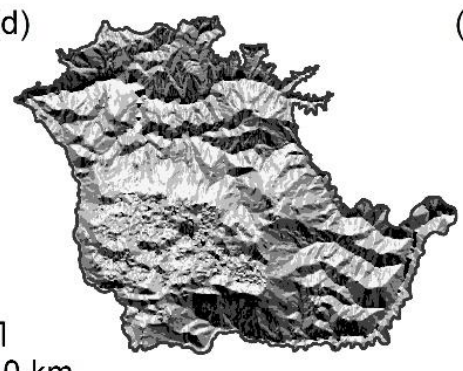

$02,55 \quad 10 \mathrm{~km}$ (b) sures (c)
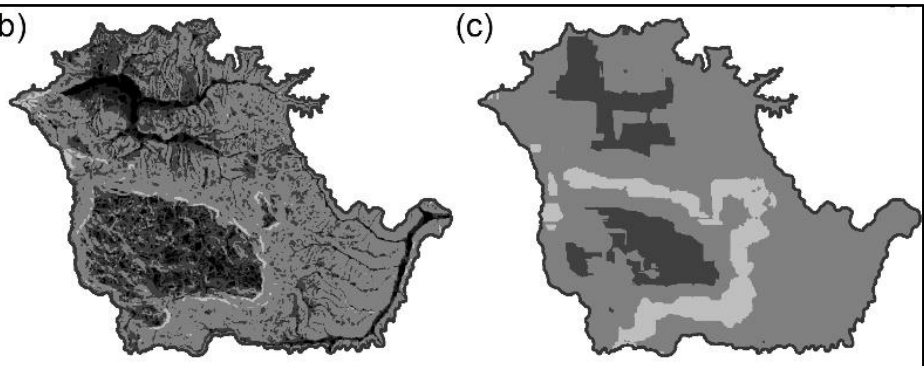

(e)

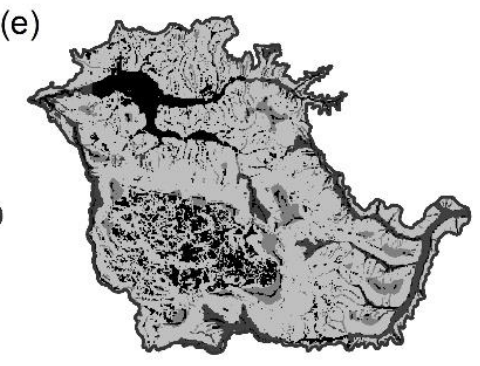

Figure 4. Criterion maps for evaluation in function of tourism: (a) elevation; (b) slope; (c) vertical dissection; (d) aspect; (e) Morphographic characteristics

After reclassification, we have obtained five criterion maps (Figure 4), which make link between evaluation and spatial data. The comparing matrix of criteria pairs, for better overview, are labeled in the order of appearance in the Table 3 (C1 - elevation; C2 - slope; C3 - vertical dissection; C4 - aspect and C5 - morphographic characteristics).

Table 4. Tabular view of comparison matrices, normalized matrix and weighting factors $(\mathrm{w})$ of reliefs criteria

\begin{tabular}{cccccc} 
& $\mathrm{C} 1$ & $\mathrm{C} 2$ & $\mathrm{C} 3$ & $\mathrm{C} 4$ & $\mathrm{C} 5$ \\
\hline $\mathrm{C} 1$ & 1 & 1 & 3 & 3 & 2 \\
\hline $\mathrm{C} 2$ & 1 & 1 & 2 & 3 & 2 \\
\hline $\mathrm{C} 3$ & 0,33 & 0,50 & 1 & 3 & 0,33 \\
\hline $\mathrm{C} 4$ & 0,33 & 0,33 & 0,33 & 1 & 0,50 \\
\hline $\mathrm{C} 5$ & 0,50 & 0,50 & 3 & 2 & 1 \\
\hline
\end{tabular}

\begin{tabular}{cccccc} 
& $\mathrm{C} 1$ & $\mathrm{C} 2$ & $\mathrm{C} 3$ & $\mathrm{C} 4$ & $\mathrm{C} 5$ \\
\hline $\mathrm{C} 1$ & 0,31 & 0,30 & 0,32 & 0,25 & 0,34 \\
\hline $\mathrm{C} 2$ & 0,31 & 0,30 & 0,21 & 0,25 & 0,34 \\
\hline $\mathrm{C} 3$ & 0,10 & 0,15 & 0,10 & 0,25 & 0,05 \\
\hline $\mathrm{C} 4$ & 0,10 & 0,10 & 0,03 & 0,08 & 0,08 \\
\hline $\mathrm{C} 5$ & 0,15 & 0,15 & 0,32 & 0,16 & 0,17 \\
\hline
\end{tabular}

\begin{tabular}{c}
$\mathbf{w}$ \\
\hline 0,3060 \\
\hline 0,2846 \\
\hline 0,1339 \\
\hline 0,0820 \\
\hline 0,1935 \\
\hline
\end{tabular}

$\mathrm{CR}=0,06$ 
Weights on which is made relief evaluation have helped the process of pointing the most suitable terrain for the development of recreational tourism. They vary in the range from 0,0820 to 0.3060 . The dominant is impact of elevation $\mathrm{w}_{1}=0.3060$ and slope $\mathrm{w}_{2}=0.2846$, while the other criterions are getting lower value. Morphographic characteristics have the most impact after elevation and slope $\left(\mathrm{w}_{5}=0.1935\right)$, followed by vertical dissection (w3 $=0.1339)$. The lowest influence has aspect $(\mathrm{w} 4=0,0820)$. Matrix consistency value is 0.06 and it is within the limits of allowed.

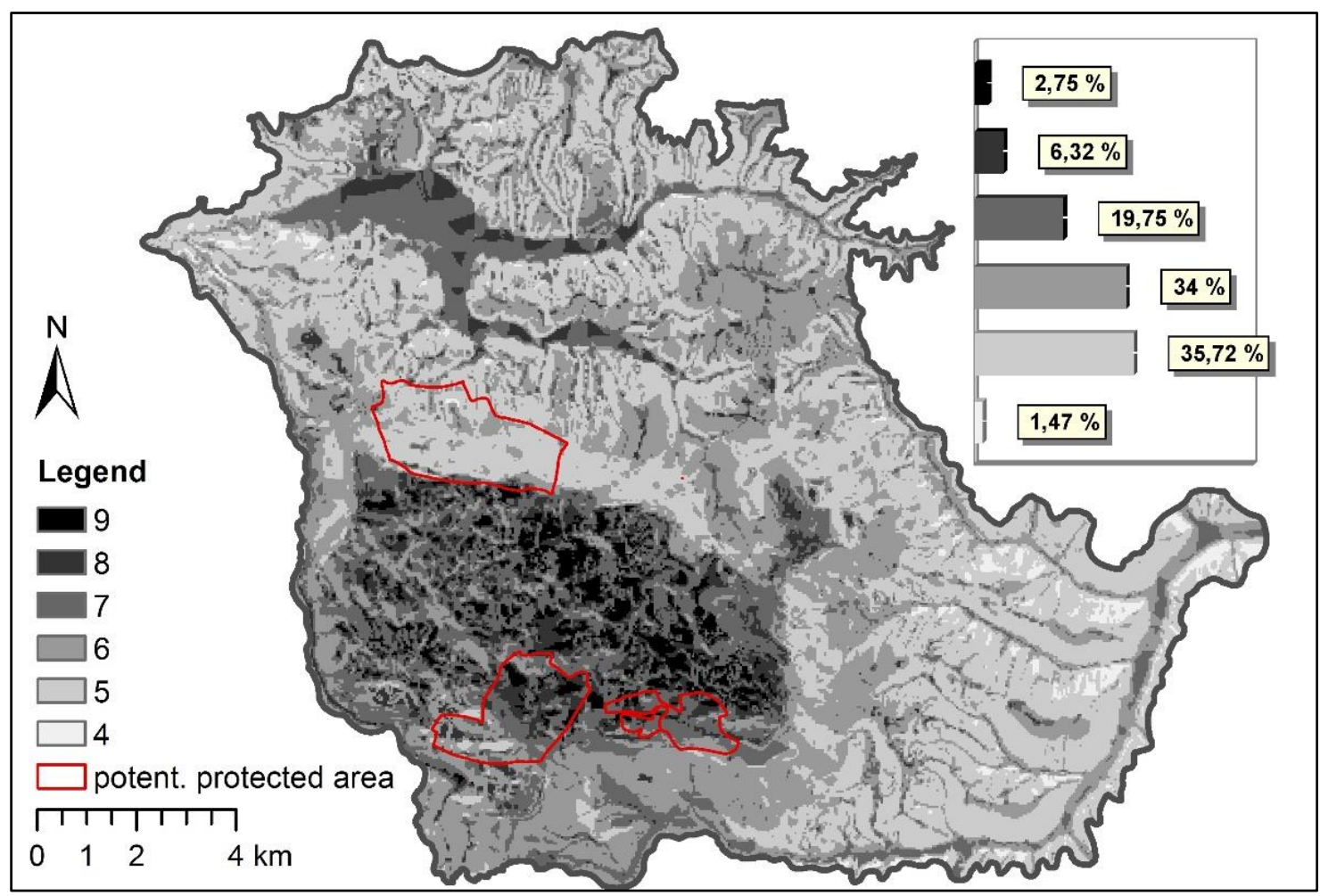

Figure 5. Map of reliefs suitability for tourism with a percentage share of evaluated categories

Results of relief evaluation for purposes of recreation and tourism are presented in form of map (Figure 5). Percentage of high score indicates that the relief criteria provide good opportunities for the development of recreational tourism. The lowest rate given by evaluation is 3,267 and the highest 8,732, and the smallest range of ratings in the range of 3 to 4 , and the greatest range is from 8 to 9 . The relief most valuable regions for the development of recreation and tourism are represented with a share of $2.75 \%$, a $6.32 \%$ of the area is rated as very suitable for the development of recreational tourism. About $20 \%$ goes into the category of predominantly valuable space, so top three most valuable categories together cover less than one third of the analyzed area (about 29\%). Lands categorized as relatively satisfying take more than a third of studied area (34\%), and mostly less suitable area $(35.72 \%)$ rated with value of 5 . With the lowest percentage are represented by areas that were characterized as predominantly unsuitable $(1.47 \%)$.

On a map of reliefs suitability are shown border of potentially protected areas that are allocated based on study Protected Landscape "Javorina", according to IUCN categorization. This study for the protection of the Jahorina mountain massif in Republika Srpska is awaiting confirmation. Three zones are characterized by high geo and biodiversity and other natural specifics fundamentals that enhance tourist attractiveness of area. 


\section{CONCLUSION}

Relief potential of an area are often basis for development of certain forms of tourism, such as: alpine, winter sport tourism, recreational tourism, etc. The overall picture of the relief value of studied area, in terms of land use for the development of recreational tourism is quite favorable. Results of the evaluation showed that the relief in the area Ravna Mountain provides a very good opportunity for the development and activation of recreational tourism. Qualitatively most valuable area affect almost a third of the studied area, together with terrains which has been classified as a relatively satisfying this relation is growing dramatically (more than half of the studied area).

Evaluation of relief showed that morphometric and morphographic characteristics of area have real possibilities for improvement of existing and the development of mass tourism activity, especially during the summer months. Most valuable spatial units are dominant and evenly grouped on area of Ravna Mountain and, to a lesser extent, in the flat part of Pale Valley. Beside relief, other physical geographical qualities of area undoubtedly have a significant impact on the ability of development and activation of tourism and recreation, as well as a good touristic-geographical position which is characterized by proximity to the emitting area of larger settlements (Sarajevo, East Sarajevo), and good transport connections. The development of recreational tourism can serve as a complementary activity to already affirmed the winter tourism on Jahorina and Ravna Mountain.

\section{REFERENCES}

[1] Bognar, A. \& Bognar, H. Geoecological evaluation of relief of the Republic of Croatia (Geoekološko vrednovanje reljefa Republike Hrvatske), International Symposium GEOECO 2010 - Geoecology - XXI century, Proceedings, Montenegro, pp 44-65, 2010.

[2] Golijanin, J., Temimović, E. \& Operta, M. Quantitative geomorphological analysis of area Ravna Mountain and Pale Valley, Acta geographica Bosniae et Herzegovinae, Bosnia and Herzegovina, 5, pp 43-53, 2016.

[3] Golijanin, J. Analysis of morphographic characteristics of relief based on DEM, case study Pale Valley and Ravna Mountain (Analiza morfografskih karakteristika reljefa na osnovu DEM-a, primjer Paljanske kotline i Ravne planine), IV Serbian geographer Congress, Proceedings, Serbia, book 1, pp 179-184, 2015.

[4] Lješević, A. M. Quantitative evaluation of natural environment (Kvantitativne metode valorizacije prirodne sredine), Protection of nature, Serbia, (36), pp 93-109, 1983.

[5] Bognar, A. Geomorphological and engineering-geomorphological characteristics of the island of Hvar and ecological evaluation of relief (Geomorfološke i inženjerskogeomorfološke osobine otoka Hvara i ekološko vrednovanje reljefa), Croatian Geographical Bulletin, Croatia, 52, pp 49-65, 1990.

[6] Golijanin, J. Geoecological evaluation of Ravna Planina terrain in the function of winter tourism, Journal of the Geographical Institute „Jovan Cvijić” SASA, Serbia, 61 (2), 1-10, 2011.

[7] Saaty, T. L. The Analytic Hierarchy Process (AHP): Planning, Priority Setting, Resource Allocation. McGrow-Hill, New York, USA, pp 437, 1980.

[8] Bunruamkaew, K. Site Suitability Evaluation for Ecotourism Using GIS \& AHP: A Case Study of Surat Thani Province, Thailand. Phd Dissertation, Graduate School of Life and Environmental Sciences, Doctoral Program in Geoenvironmental Sciences, University of Tsukuba, Japan, 129 pp, 2012. 
[9] Deng, J., King, B. \& Bauer, T. Evaluating Natural Attractions for Tourism, Annals of Tourism Research, USA, Vol. 29, No 2, pp 422-438, 2002.

[10] Dashti, P. et al. Combining Multi-Criteria Decision-Making and Geographical Information Systems for Identifying Appropriate Types of Recreation Sites, Reef Resources Assessment and management Technical Paper, France, Vol.38, pp 311-324, 2013.

[11] Aklibasinda, M. \& Jahja, B. Analysis of Terrains Suitable for Tourism and Recreation by Using Geographic Information System (GIS), Proceedings of the International Caucasian Forestry Simposium, Turkey, pp 961-969, 2013.

[12] Piran, H. et al. Site selection for local forest park using AHP and GIS (case study: Badreh County), International Research Journal of Applied and Basic Sciences, Bangladesh, Vol. 6 (7), pp 930-935, 2013. 